\title{
HOW THE GLOBAL COVID-19 PANDEMIC IS IMPACTING ON THE CARE OF PATIENTS WITH SYSTEMIC LUPUS ERYTHEMATOSUS IN AMAPÁ STATE, BRAZIL
}

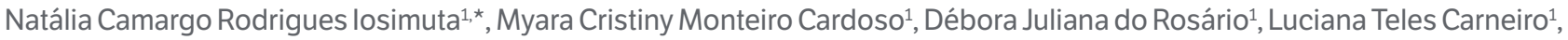
Areolino Pena Matos ${ }^{1}$

1.Universidade Federal do Amapá, Macapá (AP), Brazil.

*Corresponding author: naticrod@unifap.br

\section{BACKGROUND}

Systemic lupus erythematosus (SLE) is a systemic inflammatory autoimmune disease ${ }^{1}$ that uses antimalarial (AM) drugs, such as chloroquine (CQ) and hydroxychloroquine (HCQ), in the pharmacological approach. Hydroxychloroquine is one of the therapeutic candidates against coronavirus infectious disease 19 (COVID-19), capacity and its potential antiviral effect. Currently, it is estimated that in Brazil there are approximately 65,000 people with SLE²; and the Northern Brazil, where Amapá state is located, had a higher lupus mortality rate than the country, between the years 2002 and $2011^{3}$. The recommendation to use HCQ for COVID-19 may have seriously impacted on the access to this medication. Hence, the objective of this study is to assess the impact of the COVID-19 pandemic in Amapá on the access of SLE patients.

\section{MATERIALS AND METHODS}

Quantitative cross-sectional study assessed 91 volunteers from Amapá state, in Brazil, with SLE answered a semistructured online questionnaire from April to July 2020, to collect sociodemographic data, information about the disease, analysis of the use of HCQ and CQ, and information about COVID-19. The data were analyzed using chi-square test with a statistical significance level set at $5 \%$.

\section{RESULTS}

Among the participants, $42.9 \%$ have age range to $31-40$ years, $100 \%$ are woman, $93.4 \%$ use HCQ or CQ. During this period, $69.2 \%$ reported an increase in symptoms, such as: joint pain (67.0\%), anxiety (74.7\%), fatigue (69.0\%) and fear (48.4\%). In this region of Brazil there was HCQ or CQ shortage in the pharmacies, with $46.8 \%$ of shortage for more than 30 days $(p<$ 0.001 ), $31.6 \%$ of shortage for more than 60 days ( $p<0.001$ ), and $8.9 \%$ of shortage for more than 90 days $(p<0.001)$. Sixty percent did not have an explanation about de COVID-19 disease, 13.2\% felt yourselves protected taking HCQ or CQ, 8.8\% had or have COVID-19.

\section{CONCLUSION}

This data shows that probably the incentive to use HCQ as prevention and/or treatment of COVID-19, even without enough scientific basis to support its clinical therapeutic indication against SARS-CoV-2, negatively interfered in the access to this medication. Despite studies have shown that HCQ provides protection from flares for 3 to 6 months following withdrawal, the results from this study demonstrated that from April to June 2020 some SLE patients already described an HCQ shortage for more than 90 days. Thus, it is possible that the time without taking AM drugs will improve until the end of the 2020 year.

\section{FUNDING}

This study received funding by Programa de Auxílio a Pesquisador from Universidade Federal do Amapá (PAPESQ/ UNIFAP) 2019 


\section{REFERENCES}

1. Aringer M, Costenbader K, Daikh D, Brinks R, Mosca M, Ramsey-Goldman R, et al. 2019 European League Against Rheumatism/American College of Rheumatology classification criteria for systemic lupus erythematosus. Ann Rheum Dis. 2019;78(9):1151-9. https:// doi.org/10.1136/ annrheumdis-2018-214819

2. Sociedade Brasileira de Reumatologia [Internet]. Lúpus Eritematoso Sistêmico (LES) - Cartilha da SBR; 2011 [cited 24 Jun. 2020 ]. Avaliable from: https://www.reumatologia.org.br/orientacoes-ao-paciente/lupus-eritematoso-sistemico-les-cartilha-da-sbr/

3. Costi LR, Iwamoto HM, Neves DCO, Caldas CAM. Mortality from systemic erythematosus lupus in Brazil: evaluation of causes according to the government health database. Rev Bras Reumatol. 2017; 57(6): 574-82. https://doi.org/10.1016/j.rbre.2017.09.001

4. Fanouriakis A, Kostopoulou M, Alunno A, Aringer M, Bajema I, Boletis JN, et al. 2019 Update of the EULAR recommendations for the management of systemic lupus erythematosus. Ann Rheum Dis. 2019; 78(6): 736-45. http://doi.org/10.1136/annrheumdis-2019-215089

5. Sun X, Ni Y, Zhang M. Rheumotologitsts' view on the use of hydroxychloroquine to treat COVID-19. Emerg Microbes Infect. 2020; 9(1) :8302. https://doi.org/10.1080/22221751.2020.1760145 